\title{
高速気流中における気泡混入液体噴流の分散特性*1 Characteristics of Spatial Distribution of a Bubbling Liquid \\ Jet across a High-Speed Airstream
}

小田哲也*2 廣 安博 之*3

Tetsuya ODA and Hiroyuki HiRoyasu

Key Words : Fuels, Engines, Bubbling Liquid Jet, Cross Airstream, Spatial Distribution of Liquid

\begin{abstract}
A bubbling liquid jet was ejected normal to a highspeed airstream to control a spatial distribution of the ejected liquid under an airstream velocity of $70 \mathrm{~m} / \mathrm{s}$ and a constant injection pressure. And spray shapes were obtained by scattered-light photographs with a long exposure time and the liquid mass flow rate per unit area were measured by the mass sampling technique. The height of the maximum liquid mass flow rate per unit area in the spray hardly changed, when the ratio of the mass flow rate of the ejected liquid to standard mass flow rate decreases from $100 \%$ (without gas) to $39 \%$ increasing the gas/liquid rate. However, with decreasing the ratio, maximum mass flow rate per unit area decreased and the width of vertical and horizontal distribution of the liquid mass flow rate per unit area increased.
\end{abstract}

\section{1. 緒言}

超音速輸送機用のエンジンにはラムジェットエンジ ンやターボジェットエンジンなどの後ろに取り付けら れるアフターバーナの燃焼技術が不可欠である.これ らの燃焼器では燃料液体をインジェクタから短い距離 で微粒化することが要求される，そのため，燃焼器 入口で然料液体だけを $50 \sim 150 \mathrm{~m} / \mathrm{s}$ (マッ八数 $0.15 \sim 0.45)$ 程度の高速な気流に対して単純な円形噴 孔から垂直に噴射し，インジェクタの下流に固定した 保炎器の周囲に燃料を分散させて燃焼させることが一 般的である。

噴孔から液体を噴射すると, 噴霧液体に空間的分布 があり，保炎器付近の燃料の局所質量流量が燃焼状態 に影響する。著者らは高速な気流中に液体のみを噴射 した場合の液体の微粒化および分散過程について研究

\footnotetext{
${ }^{* 1}$ 平成 5 年 11 月 1 日, 日本航空宇宙学会西部支部講演会にて 講演。平成 8 年 2 月 23 日原稿受理

*2 現, 鳥取大学工学部

*3広島大学工学部
}

を行ってきだー3)。その結果，気流速度が大きくなる と液体の局所質量流量の最大值は大きくなり, 最大値 をとる高さ（液体の噴射方向位置. 第 2 図の $z$ 座標） は減少し液体燃料の分布範囲も狭くなった．また液体 の噴射速度を大きくすると液体の局所質量流量の最大 値は変化しないのにかかわらず, 最大值をとる高さは 增加し液体の分布範囲が広くなった。このように気流 中に単に液体だけを噴射しただけでは液体の分布する 範囲に応じて局所質量流量の最大值も変化するため燃 料液体の分布状態を制御できない．つまり，ラムジェ ットエンジンやアフターバーナ内のインジェクタ噴孔 から噴射した燃料液体の噴射量が変化すると，下流の 所定の高さに固定した保炎器の付近に燃料が到達しな くなる．近年，これを解消するために噴射直前の液体 に気泡を混入して気流中に噴射することで，所定の高 さに燃料液体を到達させるという方法が考え出され た。

Arai ら ${ }^{4)}$ は, 気泡（ヘリウムガス）を泿入した液 体 (水)の噴射圧力を一定に保つことで，両者の混合比 を変えても噴霧形状は不変であることを写真撮影によ り確認した．しかし，適量の液体を所定の領域に分布 させることができることを確認するには，液体の局所 質量流量を測定して液体の分布状況を明らかにする必 要がある。一方，インジェクタよりも上流で液体と気 体を混合すると混合割合や流路断面積などによって脈 動することがある：そこでAraiらは界面活性戍を用 いて気泡を微細にし脈動を起こりにくくしている。と ころが実用性を考えると，あらかじめ噴射液体に界面 活性剂を混合することは望ましくない。

本研究では界面活性剂を用いず，単に噴射前の液体 (水)に空気を混入して高速気流中に噴射する方法をと った。そこで，まず独自に開発したインジェクタの噴 射特性について述べる。その上で，このインジェクタ から気流中に噴射した噴霧の写真撮影や液体の局所質 
量流量の測定により，所定の高さに任意量の液体を到 達させるという制御の可能性を確認し，噴霧の分散特 性を明らかにした。

\section{2. 実験装置および方法}

2.1 吐出風洞の概略 第 1 図に吐出風洞の概略を 示す1).ターボブロア1で吸入した空気は、ディフュ 一ザ 3 で減速され整流部 4 を経て, 絞り管 5 で加速さ れた後に測定部 6 に導入される. 測定部内の気流速度 をターボブロアの吸入ロにおけるバルブにより調節し た. 測定部は内寸法が $\square 120 \times 120 \mathrm{~mm}$ の正方形断面 である透明なアクリル製ダクトである。この測定部入 口の一様気流中に気泡を混入した液体を気流に対して 垂直に噴射した．この噴射方向は鉛直上方でもある。 なお，噴射液体には水を，噴射液体に混入する気体に 空気を使用した。

座標系および液体の局所質量流量の測定装置概略を 第 2 図に示す，原点をインジェクタ噴孔とし，気流速 度 $V_{\mathrm{a}}$ の方向を $x$, 噴霧の幅の方向を $y$, 液体の噴射 速度 $V_{l}$ の方向を $z$ とした.

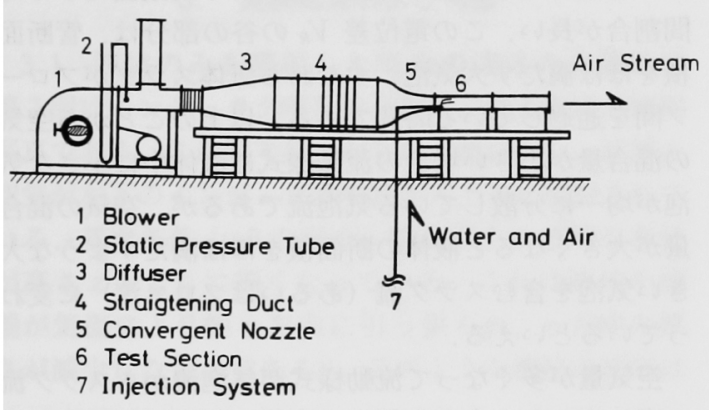

第 1 図吐出風洞の概略

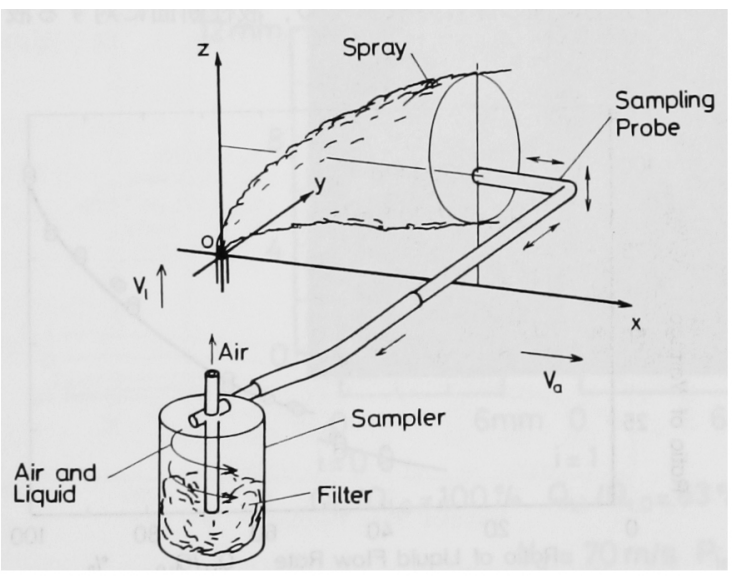

第 2 図 座標系および液体の局所質量流量の測定装置概略
この第 2 図は液体の局所質量流量の測定装置も示し ている. 液体の捕集は内径 $6 \mathrm{~mm}$, 外径 $8 \mathrm{~mm}$ のサン プリングプロープで行った.サンプリングプローブか ら流入した液体と空気は円筒形の捕集容器に側面から 流入し，容器内を旋回する過程で分離される。そして 液体を捕集して空気のみを大気中に放出した。な掖 体の捕集効率は約 $80 \%$ でった。

\section{2 噴射系および噴射特性の概略}

2.2 .1 噴射系とインジェクタの概略 本実験で使 用した気泡混入型インジェクタを第 3 図に示す。この インジェクタは右と左からそれぞ液体と空気が流入 する、インジェクタの先端には内径 $0.9 \mathrm{~mm}$, 助走距 離 $22 \mathrm{~mm}$ のステンレスパイプが付いており，このパ イプの直前において液体と空気を混合し，パイプの先 端，すなわちインジェクタ噴孔から液体と空気を同時 に噴射する，噴射圧力はインジェクタ直前のブルドン 管で，液体と空気の噴射流量は，上流における浮子式 流量計で測定した。

ここでは気流速度 $V_{a}$ を $70 \mathrm{~m} / \mathrm{s}$ として実験を行っ た。また基準の液体噴射量 $Q_{l, 0}$ を $1.12 \times 10^{-5} \mathrm{~m}^{3} / \mathrm{s}$ と

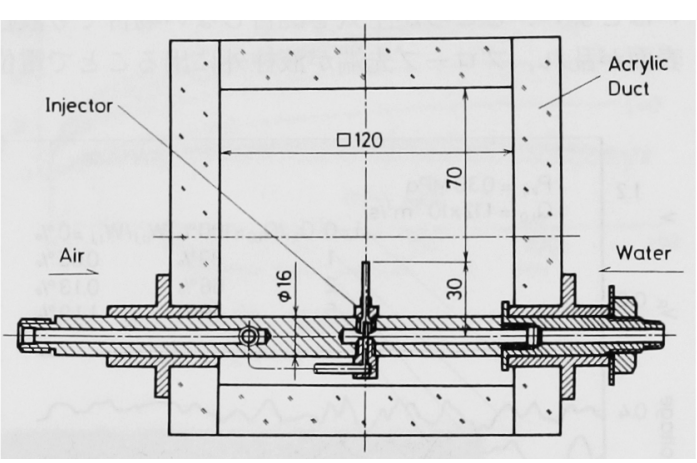

第 3 図気泡混入型インジェクタの概略

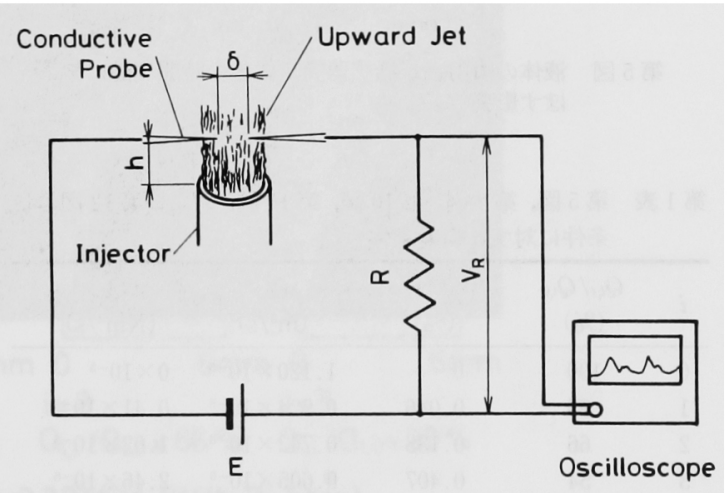

第 4 図 気泡を混入した噴射液体の流動様式の測定装置摡 略 
した，液体の噴射量を小さくする場合には，噴射圧力 $P_{i n j}$ を0.3 MPaに保ったまま混入する空気量を増加 させて気流中に噴射することとした。

2.2.2 気泡混入液体の噴射特性 液体と空気を混 合してパイプ内を流す場合, 気液混相流の流動様式は 液体と空気の流量や物性, パイプの寸法や形状, 流動 方向と体積力の方向の関係，混合方法や混合した位置 からの距離により異なる ${ }^{5}$ ，そこで噴射液体と空気の 混合量が，インジェク夕噴孔から噴射した直後におけ る気泡混入液体の流動様式におよほす影響を第 4 図の 装置で調べた，ただし，液体と空気の噴射方向を風洞 での噴射方向と同じ鉛直上方とした．この装置は単に 2 本の針状プローブと定電圧電源，抵抗器を直列に接 続したものであり，抵抗器間の電位差の時間変化を才 シロスコープで測定した。噴孔の直上における液柱 （液体の連続部分）の流動特性を調べるにはインジェ クタ噴孔から 2 本の針状プローブまでの高さが低いほ どよい. しかし抵抗器間の電位差がステンレス製のイ ンジェクタ噴孔から影響を受けにくくするため, プロ ーブを高さ $h=2 \mathrm{~mm}$ に固定した. プローブ先端間の 距離は液柱断面全体の気泡の分布状態を知るために広 いほどよい。ところが空気を混合しない場合でも液柱 表面が乱れ，プローブ先端が液柱外に出ることで電位

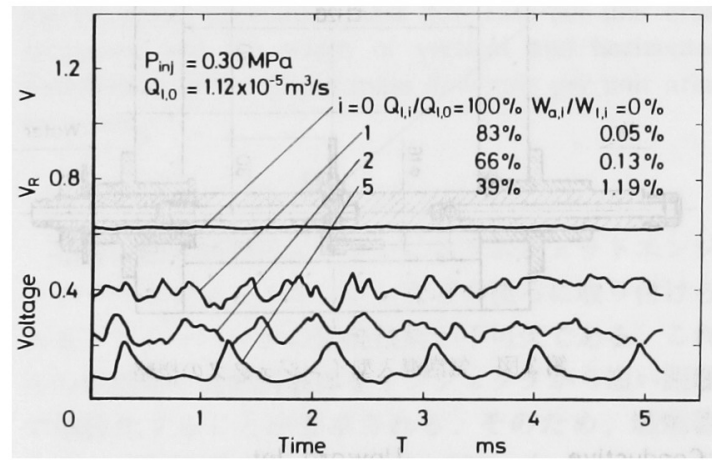

第 5 図 液体の噴射量が抵抗器間電位差の時間変動におよ 矿影響

第 1 表 第 5 図, 第 7 図, 第 10 図, 第 11 図, および第 12 図の各 条件に対する噴射条件

\begin{tabular}{ccccc}
\hline$i$ & $\begin{array}{c}Q_{t, i} / Q_{l, 0} \\
(\%)\end{array}$ & $\begin{array}{c}W_{a, i} / W_{l, i} \\
(\%)\end{array}$ & $\begin{array}{c}Q_{l, i} \\
\left(\mathrm{~m}^{3} / \mathrm{s}\right)\end{array}$ & $\begin{array}{c}Q_{a_{, i}} \\
\left(\mathrm{Nm}^{3} / \mathrm{s}\right)\end{array}$ \\
\hline 0 & 100 & 0 & $1.120 \times 10^{-5}$ & $0 \times 10^{-5}$ \\
1 & 83 & 0.046 & $0.924 \times 10^{-5}$ & $0.41 \times 10^{-5}$ \\
2 & 66 & 0.138 & $0.742 \times 10^{-5}$ & $1.02 \times 10^{-5}$ \\
3 & 54 & 0.407 & $0.605 \times 10^{-5}$ & $2.46 \times 10^{-5}$ \\
4 & 48 & 0.659 & $0.532 \times 10^{-5}$ & $3.51 \times 10^{-5}$ \\
5 & 39 & 1.193 & $0.441 \times 10^{-5}$ & $5.27 \times 10^{-5}$ \\
\hline
\end{tabular}

差信号に波形が現れることがある．そこで針状プロー ブの間隔を $\delta=0.6 \mathrm{~mm}$ とした。

噴射液体に混入した空気量が抵抗器間の電位差 $V_{R}$ の時間変動に㧈よほす影響を調べると，第 5 図のよう になった。また第 1 表に，第 5 図や後述の第 7 図，第 10 図，第 11 図，および第 12 図中の条件 $i$ に対する 噴射条件，すなわち液体の噴射量 $Q_{l, i}$, 空気の噴射量 $Q_{a, i}$, 基準条件 $\left(i=0, Q_{l, 0}=1.12 \times 10^{-5} \mathrm{~m}^{3} / \mathrm{s}, Q_{a, i}=\right.$ $0 \mathrm{~m}^{3} / \mathrm{s}$ ）に対する液体の噴射流量割合 $Q_{l, i} / Q_{l, 0}$, およ び噴射液体に対する空気の混入質量割合 $W_{a, i} / W_{l, i}$ を 示す. 基準条件，つまり空気を混合しない場合プロー ブ間は常に液体で満たされ，電極間は導通状態にある ため電位差 $V_{R}$ に時間変動はみられない，液体の噴射 量 $Q_{l, i} / Q_{l, 0}$ が $83 \%$ および $66 \%$ の場合，つまり空気混 合量を小さくすると電位差 $V_{R}$ が小さくなり波形が不 規則になる。ここで, 電位差 $V_{R}$ の波形の山の部分は 両プローブ間に液体が多く存在し, 谷の部分は気泡が 多く存在することを示している. 液体の噴射量 $Q_{t, i} /$ $Q_{\iota, 0}$ が $39 \%$ まで小さくなると, 電位差 $V_{R}$ の山と谷が 周期的に現れている. しかも谷の部分では電位差 $V_{R}$ が一定值に近く，山の部分に比べて 1 周期当たりの時 間割合が長い。この電位差 $V_{R}$ の谷の部分は, 管断面 積をほほ満たす大気泡，すなわち気体スラグがプロー ブ間を通過している時間である．以上のことから空気 の混合量が小さい場合の流動様式は液体中に小さな気 泡が均一に分散している気泡流であるが，空気の混合 量が大きくなると液体の断面積をほ济満たすような大 きい気泡を含むスラグ流（あるいはフロス流）に変わ っているといえる.

空気量が多くなって流動様式が気泡流からスラグ流 に変わるとき, 小さな気泡が合体して直径が夜柱ある いは噴孔の直径に近くなるとともに, 液体が気体スラ グの上下に押し除けられるため, 液柱断面に対する液

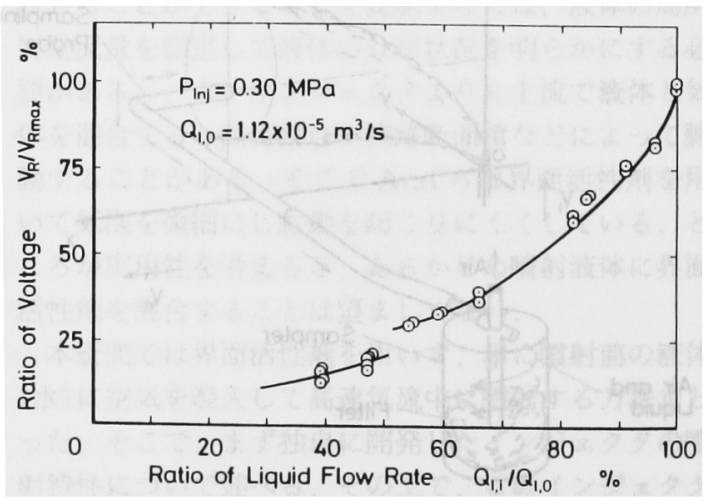

第 6 図 液体の噴射量が抵抗器間電圧におよほすす影響 
体と空気の面積割合が時間的に大きく変動するように なると考えられる5).すると電位差 $V_{R}$ の山と谷の差 が大きくなると思われる．よって電位差 $V_{R}$ の最小值 は流動様式を特徵づける気泡の直径と対応していると いえる。そこで第 5 図で示したような電位差 $V_{R}$ の時 間変動を第 6 図のように再整理した，第 6 図の横軸は 基準条件に対する液体の噴射量割合 $Q_{l, i} / Q_{l, 0}$ である. 一方, 綎軸は電位差の時間変化の最小值 $V_{R}$ を基準条 件の電位差 $V_{R \text { max }}$ で割った值 $V_{R} / V_{R \max }$ である，基準 条件である液体の噴射量割合 $Q_{l, i} / Q_{l, 0}$ が $100 \%$ の場 合，液柱は気泡を含まず電位差 $V_{R} / V_{R \max }$ が $100 \%$ で ある。この条件から液体の噴射量を小さくすると電位 差 $V_{R} / V_{R \max }$ は次第に小さくなる，次いで液体の噴射 量 $Q_{l, i} / Q_{l, 0}$ が $50 \%$ 程度のとき，電位差 $V_{R} / V_{R \max }$ が 急に小さくなり，再び緩やかに隇少する。このことは 液体の噴射流量が $50 \%$ 程度において液柱の流動樣式 が変化することを示しており，液体の噴射量 $Q_{l, i} / Q_{\iota, 0}$ が 50\%程度以上のときは液柱は気泡流，液体の噴射 量 $Q_{l, i} / Q_{\ell, 0}$ が $50 \%$ 程度以下のときはスラグ流である ということができる。

\section{3. 実験結果および考察}

3.1 液体のみを噴射した場合の液体の分散特性 第 7 図はインジェク夕噴孔の近傍における噴霧の瞬間 写真である。この図では左からの気流に対し, 液体と 空気が左下のインジェクタ噴孔から上方に噴射されて いる. 基準条件 $i=0$ の場合, 噴孔直上の透明な液柱 が高さ $z$ ともに細くなっている。これは液柱の側 端が気流により幅 $y$ 方向に引つ張られ， $x$ 方向の厚 さが减少したためである゙1。このような液柱の変形は
気泡を混入しない場合に一般的にみられる。

本項では，噴射液体に気泡を混入したときと比較す るため，まず噴射直前の液体に気泡を混入しない場合 の噴霧について示す。第 8 図は液体の噴射量 $Q_{l, j}$ が 噴霧外形におよぼす影響であり，第 2 表は第 8 図や後 述の第 9 図中の条件 $j$ に対する液体の噴射量 $Q_{l, j}$, 基 準条件 $\left(j=0, P_{i n j}=0.3 \mathrm{MPa}, Q_{l, 0}=1.12 \times 10^{-5} \mathrm{~m}^{3} / \mathrm{s}\right.$, $Q_{a .0}=0 \mathrm{~m}^{3} / \mathrm{s}$ ） に対する液体の噴射量割合 $Q_{l, j} / Q_{l, 0}$, 噴射圧力 $P_{i n j}$ と液体の噴射速度 $V_{i n j}$ である. 第 8 図 の実線は後方からの連続露光による散乱光写真によっ て得た噴霧形状であり，噴霧上方の実線を噴霧の外縁 と呼ぶこととする．第 8 図では噴射量の減少に伴い噴 霧の外緑の高さ $z$ が小さくなっている。これは液体 の噴射量 $Q_{\ell, j}$ が減少すると噴射圧力 $P_{i n j}$ と噴射速度 $V_{i n j}$ が減少するためである. 条件 $j=0,2$ の噴霧につ いてインジェク夕噴孔から $x=100 \mathrm{~mm}$ の位置におけ る液体の局所質量流量 $m$ ，在測定すると，第 9 図(a)

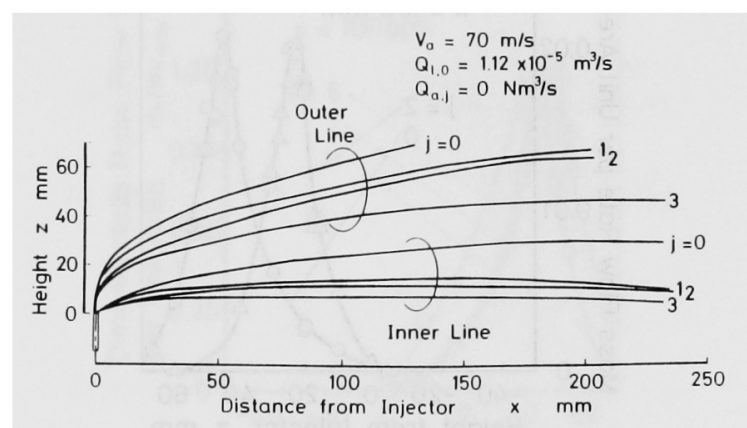

第 8 図 液体の噴射量が噴霧形状におよほす影響（液体の み噴射した場合)

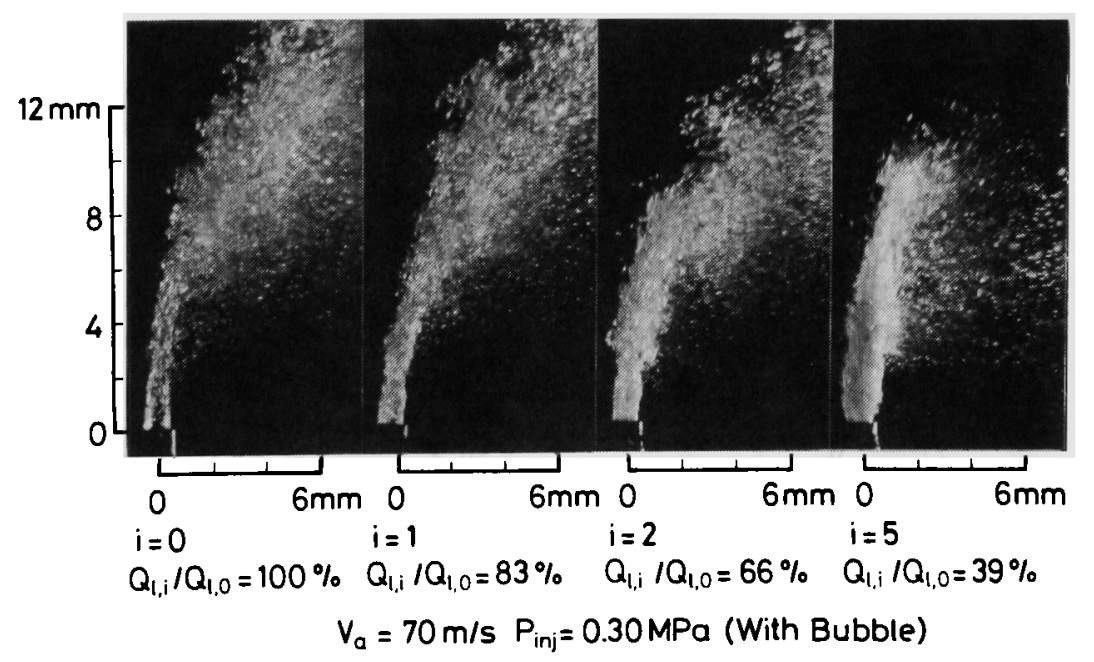

第 7 図インジェク夕近傍における噴挘の瞬間写真 
のようになった．液体の噴射量 $Q_{l, j}$ を小さくすると 液体の局所質量流量 $m_{l}$ が最大となる高さ $z$ が低くな っている。ところが萑体の局所質量流量 $m$ ，の最大値 には液体の噴射流量 $Q_{\iota, j}$ の減少による差がみられな い.さらに液体の局所質量流量 $m_{l}$ が最大となる高さ

第 2 表 第 8 図,第 9 図の各条件に対する噴射条件

\begin{tabular}{ccccc}
\hline$j$ & $\begin{array}{c}Q_{l, j} / Q_{l, 0} \\
(\%)\end{array}$ & $\begin{array}{c}Q_{l, j} \\
\left(\mathrm{~m}^{3} / \mathrm{s}\right)\end{array}$ & $\begin{array}{c}P_{i n j} \\
(\mathrm{MPa})\end{array}$ & $\begin{array}{c}V_{i n j} \\
(\mathrm{~m} / \mathrm{s})\end{array}$ \\
\hline 0 & 100 & $1.120 \times 10^{-5}$ & 0.30 & 17.6 \\
1 & 83 & $0.924 \times 10^{-5}$ & 0.20 & 14.5 \\
2 & 66 & $0.735 \times 10^{-5}$ & 0.13 & 11.6 \\
3 & 55 & $0.616 \times 10^{-5}$ & 0.10 & 9.7 \\
\hline
\end{tabular}

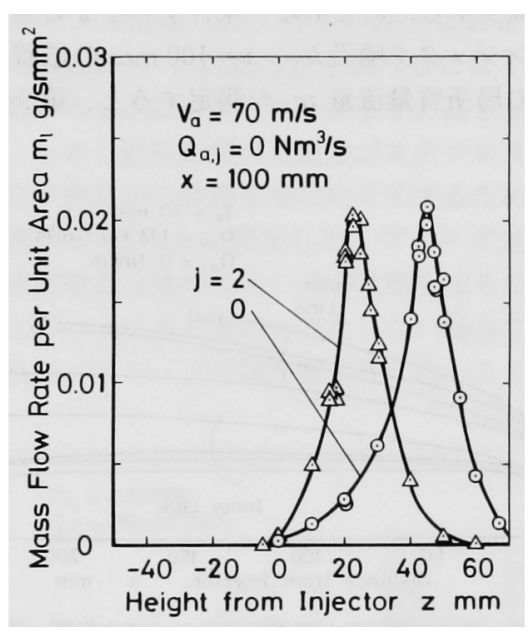

(a) 垂直方向の分布

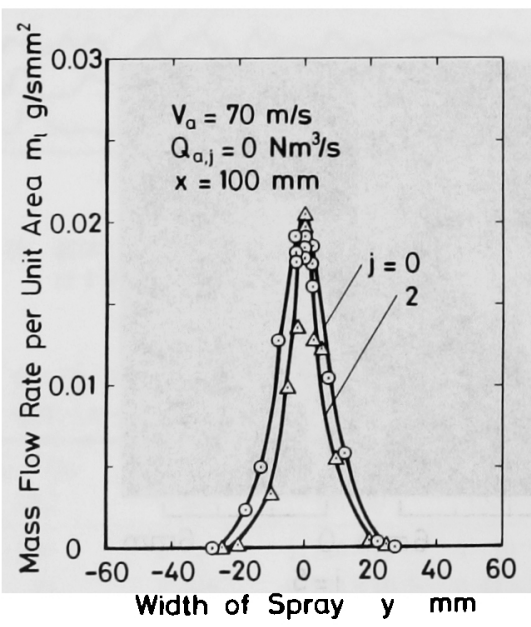

(b) 水平方向の分有

第 9 図 液体の噴射量が液体の局所質量流量におよほす影 望（液体のみ噴射した場合） $z$ における液体の局所質量流量 $m \iota$ の $y$ 方向分布を第 9 図（b）に示す，液体の噴射量が小さくなると液体の 局所質量流量 $m_{\iota}$ の $y$ 方向の分布が狭くなっている. よって通常のようにインジェクタから液体だけを噴射 する方法では，液体の局所質量流量 $m_{1}$ が最大となる 高さ $z$ を変化させず液体の局所質量流量 $m$ ，の大きさ だけを制御することは不可能であることがわかる。な お，この結果は気流速度が異なる場合にもみられた。

3.2 噴射液体に空気を湜入した場合の液体の分散 特性 第 7 図の条件 $i=1,2$ おょび 5 の噴霧では， 条件 $i=0$ の噴霧より液体の噴射量を小さくした代わ りに，空気をあらかじめ噴射液体に混入して噴射圧力 $P_{i n j}$ を一定に保っている。これらの液柱は気泡を含ん ているためインジェクタ近傍で白濁している。また， 空気を混合しない条件 $i=0$ の場合, 液柱の太さが高 さ $z$ とともに細くなっているのに対し，空気を含む 場合には細くなっていない。これはインジェクタ噴孔 から噴射した液柱内の気泡が膨張したためといえる. 条件 $i=5$ の場合，インジェクタ噴孔の直上で液柱が 太くなっているだけでなく，高さが約 $3 \mathrm{~mm}$ 以上にな ると液柱から形成された液滴が直ちに気流に流されて いる。ささらに，約 $12 \mathrm{~mm}$ 以上では液滴が見えておら ず，噴霧の到達する高さ $z$ が小さい．なお条件 $i=5$ の場合，第 5 図で説明したようにインジェクタ噴孔で の気泡混入液体の流動様式がスラグ流になっている.

上記の結果から液滴の分散には外部からの気流によ る作用に加えて，液体噴流内の気泡も影響すると考え られる.そこで連続露光による噴霧の散乱光写真撮影 を行ったところ第 10 図のようになった．気泡を混合 した液体を噴射した条件 $i=1 \sim 4$ の噴霧では外縁の高 さ $z$ に差が見られないが，気泡を混合しない液体を 噴射した条件 $i=0$ と比べると外縁の高さ $z$ が大きく なっている. 条件 $i=5$ の噴霧では外縁の高さ $z$ が条 件 $i=1 \sim 4$ よりもさらに大きくなっており，第 7 図の

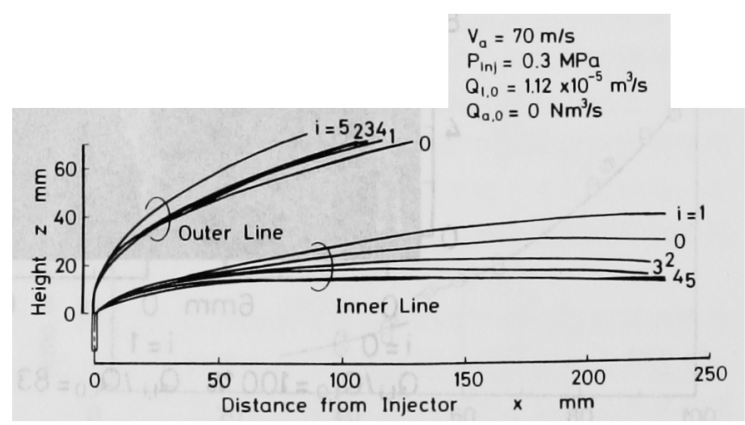

第 10 図 夜体の噴射量が噴霧形状におよほす影響（気泡 混入液体を噴射した場合) 
瞬間写真と異なった結果になっている。この理由につ いては後述することとする．なお，第 10 図の傾向は 他の気流速度の場合にもみられた。

つぎに第 10 図の各噴霧の中から，噴射液体に気泡 を含まない $i=0$ の噴霧, 気泡を比較的少量だけ含む $i=2$ の噴雺，および気泡を多量に含む $i=5$ の噴霧を 選択しインジェクタ噴孔から $x=100 \mathrm{~mm}$ の位置にお ける液体の局所質量流量 $m_{l}$ を測定すると第 11 図 (a)のようになった．この図では液体の噴射量 $Q_{l, i} /$ $Q_{l, 0}$ の減少により液体の局所質量流量 $m_{l}$ の最大とな る高さ $z$ が変化しておらず, 液体の局所質量流量 $m_{t}$ の最大値が減少している。これは夜体の噴射量 $Q_{l, i} /$ $Q_{l, 0}$ を小さくすると同時に噴射圧力 $P_{i n j}$ を一定に保つ
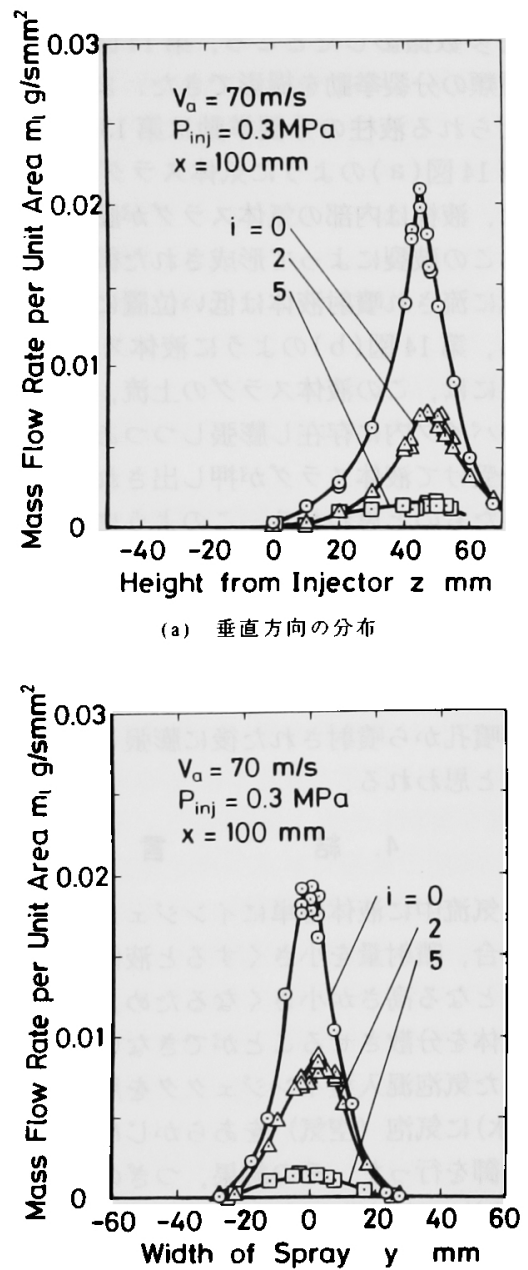

(b) 水平方向の分布

第 11 図 液体の噴射量が液体の局所質量流量におよほす 影䈉（気泡混入液体を噴射した場合）
よう噴射液体に気泡を混入したため，時間および噴孔 断面で平均した噴射夜体の運動量が，気泡を含まない 基準条件の場合と等しくなったためということができ る。

さらに液体の局所質量流量 $m_{l}$ が最大となる高さ $z$ における液体の局所質量流量 $m$ 丨 $y$ 方向分布を第 11 図(b)に示す.気泡混入量が少ない条件 $i=2$ で は，液体の局所質量流量 $m_{l}$ の分布形状が気泡を含ま ない条件 $i=0$ と同様にみえる。しかし，気泡混入量 が多い条件 $i=5$ の場合，条件 $i=0 ， 2$ とは分布形状 が異なり均一に近い.このことは第 11 図(a)の場合 にもいえる．そこで第 11 図(a)，(b)の各曲線をそ れぞれの最大值で割って無次元化すると, 第 12 図 (a)，（b）となった，第 12 図(a)の条件 $i=2$ の場

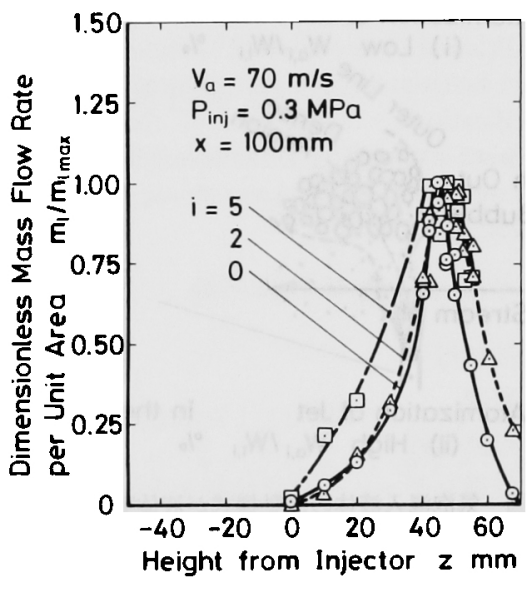

(a) 垂直方向の分有

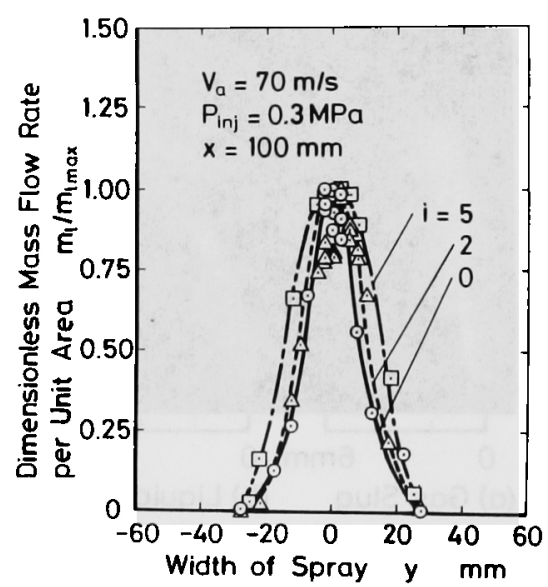

(b) 水平方向の分布

第 12 図 液体の噴射量が液体の無次元局所質量流量にお よほす影響（気泡混入液体を噴射した場合） 
合，液体の局所質量流量 $m_{1}$ が最大となる高さ $z$ 以下 で条件 $i=0$ の分布と良く一致しているが，液体の局 所質量流量 $m_{l}$ が最大となる高さ以上では条件 $i=0$ より大きい. しかし第 12 図(b)では条件 $i=2$ と条件 $i=0$ に分布形状の差がない.ここで第 13 図(i)に， 第 7 図の写真の $i=1 ， 2$ から想像できる液柱の分裂挙 動を示す. 条件 $i=1 ， 2$ のように気泡流を高速気流中 に噴射する場合，気泡の量が少ないため液柱の微粒化

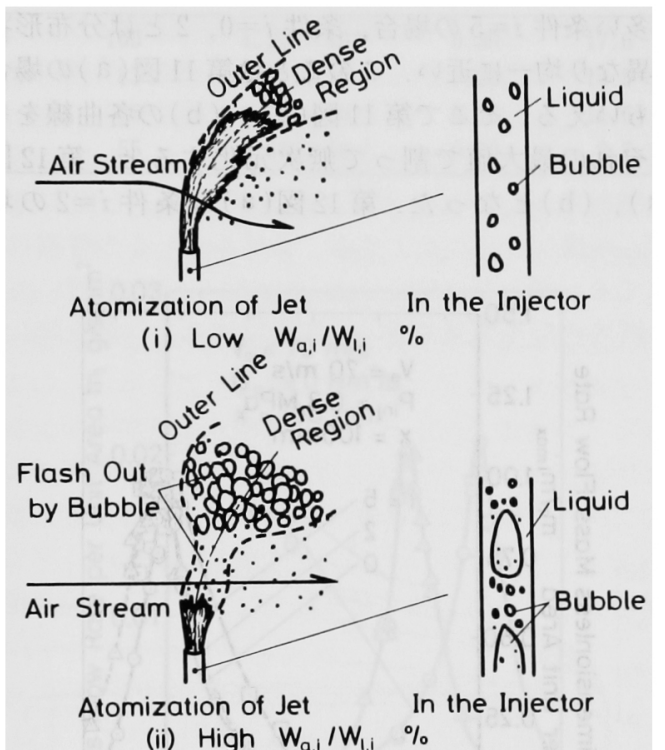

第 13 図気泡混入液体の流動様式が湤体噴流の分裂およ び分散挙動におよほす影響の概略

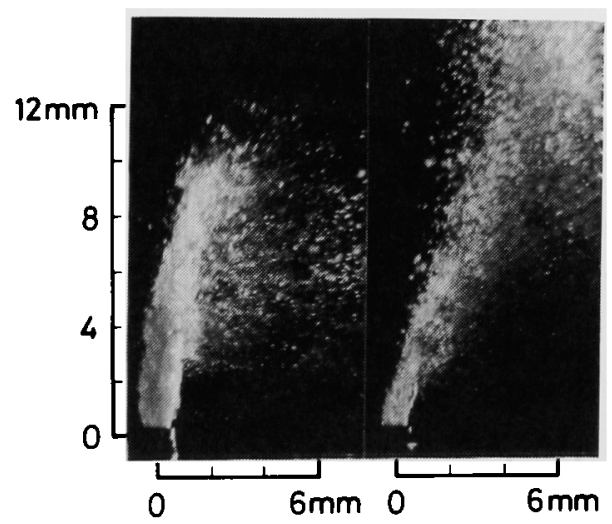

(a) Gas Slug

(b) Liquid Slug

$V_{a}=70 \mathrm{~m} / \mathrm{s} \quad P_{\text {inj }}=0.30 \mathrm{MPa} \quad Q_{1, i} / Q_{1,0}=39 \%$ $W_{a, j} / W_{1, j}=1.193 \%$

第 14 図 スラグ流をインジェクタから噴射した場合の瞬 間写真
や液体の分散におよほす気泡の膨張の影響は䫓著でな

く，液体のみを噴射したときの微粒化，分散過程に近 い，ただし噴霧上部では，液体だけ噴射した場合より も噴射した液体が多く存在している。

第 12 図(a)の条件 $i=5$ の場合, 液体の局所質量流 量 $m_{\iota}$ が最大となる高さ $z$ 以下においても液体の局所 質量流量 $m_{l}$ が大きくなっている．この条件では噴射 する気泡の混入量が大きく、インジェクタ噴孔内部で 管断面積をほ满をす大きさの気泡が周期的に現れる スラグ流(あるいはフロス流) となっていることを 2.2.2 項で述べた。この流動様式をとる場合，大きな 気泡である気体スラグが噴孔から噴射される瞬間と， 気泡間の液体塊，つまり淮体スラグが噴射される瞬間 では微粒化挙動が異なっており，液体の分布状況に影 響しているものと想像できる．そこで条件 $i=5$ の瞬 間写真を多数撮影したところ，第 14 図(a)，（b)に 示す 2 種類の分裂挙動を撮影できた．また，この写真 から考えられる液柱の分裂挙動は第 13 図（ii）とな った。第 14 図(a)のように気体スラグが噴射される 瞬間には，液柱は内部の気体スラグが膨張することで 破裂し，この破裂によって形成された微細な液滴が直 ちに気流に流され噴射液体は低い位置に分散する。 そ れに対し，第 14 図(b)のように液体スラグが噴射さ れるときには，この液体スラグの上流，つまりインジ ェクタのパイプ内に存在し膨張しつつある気体スラグ の圧力を受けて液体スラグが押し出され噴射速度が大 きくなったものと思われる。このようにして液柱の流 動様式がスラグ流の場合，液体が広い範囲，すなわち 高い位置にも低い位置にも分散するようになったとい える。一方，第 12 図(b)では条件 $i=5$ の分布の幅が 他の条件のものよりも大きくなっている。これは大き い気泡が噴孔から噴射された後に膨張して液柱が分裂 したためと思われる。

\section{4. 結言}

高速な気流中に液体を単にインジェクタ噴孔から噴 射する場合，噴射量を小さくすると液体の局所質量流 量の最大となる高さが小さくなるため，所定の高さに 適量の液体を分散させることができない，そこで独自 に開発した気泡混入型インジェクタを用い，噴射直前 の液体(水)に気泡（空気）をあらかじめ混入して噴霛 の分散制御を行った．その結果，つぎの結論を得た．

（1）液体の噴射量を減少させ，噴射圧力が一定と なるように空気を混入してゆくと，液体の局所質量流 量が最大となる高さは空気の混合割合に依存しなかっ た，それに対し，液体の局所質量流量の最大值は減少 した。すなわち，液体が最も多く分布する高さを変え 
ることなく，液体の局所質量流量の最大值だけを制御 できた。

（2）気泡混入量が増加すると噴射液体の分布範囲 が広くなった

また，噴射液体の分布形状は噴射直後における気泡 混入夜体の流動様式に依存した。すなわち，

（3）気泡流という流動様式にある気泡混入液体を 高速気流中に噴射する場合，噴霧形状は変化しなかっ た。しかし，水のみを噴射した場合に比べると噴霧上 部の夜体の局所質量流量分布が広くなった。一方，幅 方向の分布については差がみられなかった。

（4）スラグ流という流動様式にある気泡混入液体 を噴射すると，噴霧上部および下部で液体が広く分散 した。また，幅方向にも液体が広く分散した。

\section{参 考 文 献}

1）小田哲也，廣安博之，新井雅隆，西田恵哉：高速気流中におけ る液体噴流の微粒化特性（第 1 報，噴霧形状，液体の局所質 量流量とザウタ平均粒径の测定)，日本機械学会論文集 B, 58 (1992), pp. 2595-2601.

2）小田哲也, 廣安博之, 新井雅隆, 西田恵哉：高速気流中におけ る液体喷流の微粒化特性 (第 2 報, 噴射液体の局所質量流量, 液滴径の変化と軌跡の計算)，日本機械学会論文集 $\mathrm{B}, 58$ (1992), pp. 2602-2606.

3）小田哲也，廣安博之，西田恵哉：高速気流中における液体噴 流の微粒化特性（第 3 報，液体噴流の分裂過程と噴霧の内部 構造)，日本機械学会諭文集 B, 59 (1993)，pp. 1408-1413.

4) Arai, T. and Schetz, J. A. : Penetration and Mixing of Bubbling Liquid Jets from Multiple Injectors Normal to a Supersonic Air Stream, 4th International Aerospace Planes Conference, Orlando, FL, December 1992.

5）日本機械学会：気液二相流技術ハンドブック，コロナ社，東 京, 1982, pp. 1-21. 